\title{
HUBUNGAN ANTARA KEPATUHAN PENGGUNAAN OBAT DAN KEBERHASILAN TERAPI PADA PASIEN HIPERTENSI DI RUMAH SAKIT DAERAH SURAKARTA TAHUN 2010
}

\section{CORRELATION BETWEEN MEDICATION ADHERENCE WITH THERAPEUTIC OUTCOME IN HYPERTENSION PATIENTS AT RUMAH SAKIT DAERAH SURAKARTA IN 2010}

\author{
Nurul Mutmainah*, Mila Rahmawati \\ Fakultas Farmasi Universitas Muhammadiyah Surakarta \\ nurul.ums@gmail.com
}

\begin{abstract}
ABSTRAK
Hipertensi merupakan penyakit kronis yang perlu diterapi dengan tepat dan terus menerus. Salah satu penentu keberhasilan terapi adalah adanya kepatuhan penggunaan obat oleh pasien. Adanya ketidakpatuhan berakibat tidak tercapainya tujuan terapi. Penelitian ini bertujuan mengetahui hubungan antara kepatuhan penggunaan obat dengan keberhasilan terapi pada pasien hipertensi di RS Daerah Kota Surakarta. Penelitian ini menggunakan jenis penelitian non eksperimental dengan rancangan analisis cross sectional dan pengambilan datanya menggunakan metode prospektif. Penelitian ini dilakukan pada 23 pasien hipertensi rawat jalan di Rumah Sakit Daerah Surakarta, yang melakukan kontrol dan mendapat antihipertensi pada bulan SeptemberOktober tahun 2010 dimana sampel diambil dengan teknik purposive sampling. Hubungan skor kepatuhan dengan penurunan tekanan darah dianalisis menggunakan korelasi product moment. Ditemukan bahwa penyakit hipertensi lebih banyak diderita oleh perempuan dengan usia 47-60 tahun (52,2\%). Penyakit lain yang juga diderita oleh pasien hipertensi terbanyak adalah diabetes mellitus (34,8\%). Terapi antihipertensi yang banyak diberikan adalah dalam bentuk kombinasi 2 jenis obat yaitu Angiotensin Converting Enzym Inhibitor (ACEI) dan diuretik (34,8\%). Sedangkan kepatuhan pasien ditemukan pada tingkat sedang $(30,4 \%)$ dan tinggi $(69,6 \%)$ dan dari analisis korelasi product moment ditemukan korelasi antara skor kepatuhan dengan penurunan tekanan darah sangat rendah, dimana tingkat kepatuhan mempengaruhi keberhasilan terapi sebesar $18,03 \%$.
\end{abstract}

Kata kunci: Hipertensi, kepatuhan, keberhasilan terapi

\section{ABSTRACT}

Hypertension is a chronic disease that needs to be treated properly and continuously. One of the critical success of therapy is medication adherence by patients. The existence of nonadherence did not result in the achievement of therapeutic goals. This study aims to determine the correlation between medication adherence with therapeutic outcome in hypertensive patients at Rumah Sakit Daerah Surakarta. This research is non-experimental study with cross sectional design analysis and retrieval of data using the prospective method. The study was conducted in 23 patients with hypertension outpatient RS Daerah Surakarta, who received antihypertensive, where samples were taken by purposive sampling technique Correlation between scores adherence with reductions in blood pressure were analyzed using product moment correlation. It was found that hypertension affects more women age 47-60 years (52.2\%). Other diseases are also suffered by most patients with hypertension are diabetes mellitus (34.8\%). Many antihypertensive therapy is provided in the form of a combination of two types of drugs are angiotensin converting enzyme inhibitors (ACEI) and diuretics (34.8\%). While patient adherence was found at a moderate level (30.4\%) and high (69.6\%) and the product moment correlation analysis found a correlation between adherence with blood pressure reduction very weak, which that medication adherence affects therapeutic outcome of $18.03 \%$.

Key words: hypertension, medication adherence, therapeutic outcome

\section{PENDAHULUAN}

Tekanan darah tinggi (hipertensi) merupakan masalah besar, tidak hanya di negara barat tetapi juga di Indonesia. Di Indonesia banyaknya penderita hipertensi diperkirakan 15 juta orang tetapi hanya $4 \%$ yang merupakan hipertensi terkontrol. Prevalensi $6-15 \%$ pada orang dewasa, $50 \%$ diantaranya tidak menyadari sebagai penderita hipertensi sehingga mereka cenderung untuk menjadi hipertensi berat karena tidak menghindari dan tidak mengetahui faktor risikonya, dan 90\% merupakan hipertensi esensial (Armilawaty,dkk., 2007).

Tujuan pengobatan pada penderita hipertensi adalah untuk meningkatkan kualitas 
hidup. Akan tetapi banyak yang berhenti berobat ketika merasa tubuhnya sedikit membaik. Sehingga diperlukan kepatuhan pasien yang menjalani pengobatan hipertensi agar didapatkan kualitas hidup pasien yang lebih baik. Faktor yang mempengaruhi ketekunan pasien dalam berobat antara lain tingkat penghasilan, tingkat pendidikan pasien, kemudahan menuju fasilitas kesehatan, usia pasien, tersedianya asuransi kesehatan yang meringankan pasien dalam membayar biaya pengobatan (Wibawa, 2008).

Kepatuhan minum obat pada penderita hipertensi sangat penting karena dengan minum obat antihipertensi secara teratur dapat mengontrol tekanan darah penderita hipertensi. Sehingga dalam jangka panjang risiko kerusakan organ-organ penting tubuh seperti jantung, ginjal, dan otak dapat dikurangi. Menurut laporan WHO pada tahun 2003, kepatuhan rata-rata pasien pada terapi jangka panjang terhadap penyakit kronis di negara maju hanya sebesar $50 \%$ sedangkan di negara berkembang, jumlah tersebut bahkan lebih rendah (BPOM,2006)

Berdasarkan permasalahan di atas, maka perlu diketahui tingkat kepatuhan penggunaan obat pada pasien hipertensi di RSUD Kota Surakarta serta hubungannya dengan keberhasilan terapi yang dicapai.

\section{METODE PENELITIAN \\ Rancangan Penelitian}

Penelitian ini termasuk jenis penelitian non eksperimental dengan rancangan analisis cross-sectional. Pengambilan data dilakukan secara prospektif

\section{Variabel Penelitian}

1. Variabel tergantung (dependent): penurunan tekanan darah.

2. Variabel bebas (independent) : kepatuhan pasien

\section{Subyek Penelitian}

Kriteria subyek penelitian meliputi:

1. Pasien rawat jalan di RS Daerah Surakarta bulan September-Oktober 2010

2. Terdiagnosa hipertensi minimal 2 bulan sebelumnya

3. Mendapat obat antihipertensi

4. Umur antara 17-60 tahun.

5. Minimal melakukan kontrol 1 bulan sebelumnya

6. Bersedia mengikuti wawancara.

\section{Alat dan Bahan}

Alat

Kuesioner kepada pasien terdiri dari 3 bagian yaitu:

Bagian A tentang demografi pasien

Bagian B tentang pengukuran Medication

Taking Scale (terdiri dari 6 pertanyaan)

Bagian C tentang pengukuran kepatuhan penggunaan obat (terdiri dari 5 pertanyaan)

\section{Bahan}

Catatan rekam medis pasien meliputi: nama, No RM, riwayat penyakit, hasil pengukuran tekanan darah (pada saat kontrol bulan lalu dan pada saat kontrol bulan ini), obat yang digunakan, hasil pemeriksaan laboratorium

Analisis Data

1. Penilaian Skor kepatuhan dari kuesioner Skor nilai kepatuhan didapatkan dari jumlah seluruh skor pasien dari pertanyaan no. 1 10 dengan range skor 1-13.

Tabel 1- Skoring kuesioner pengukuran tingkat kepatuhan

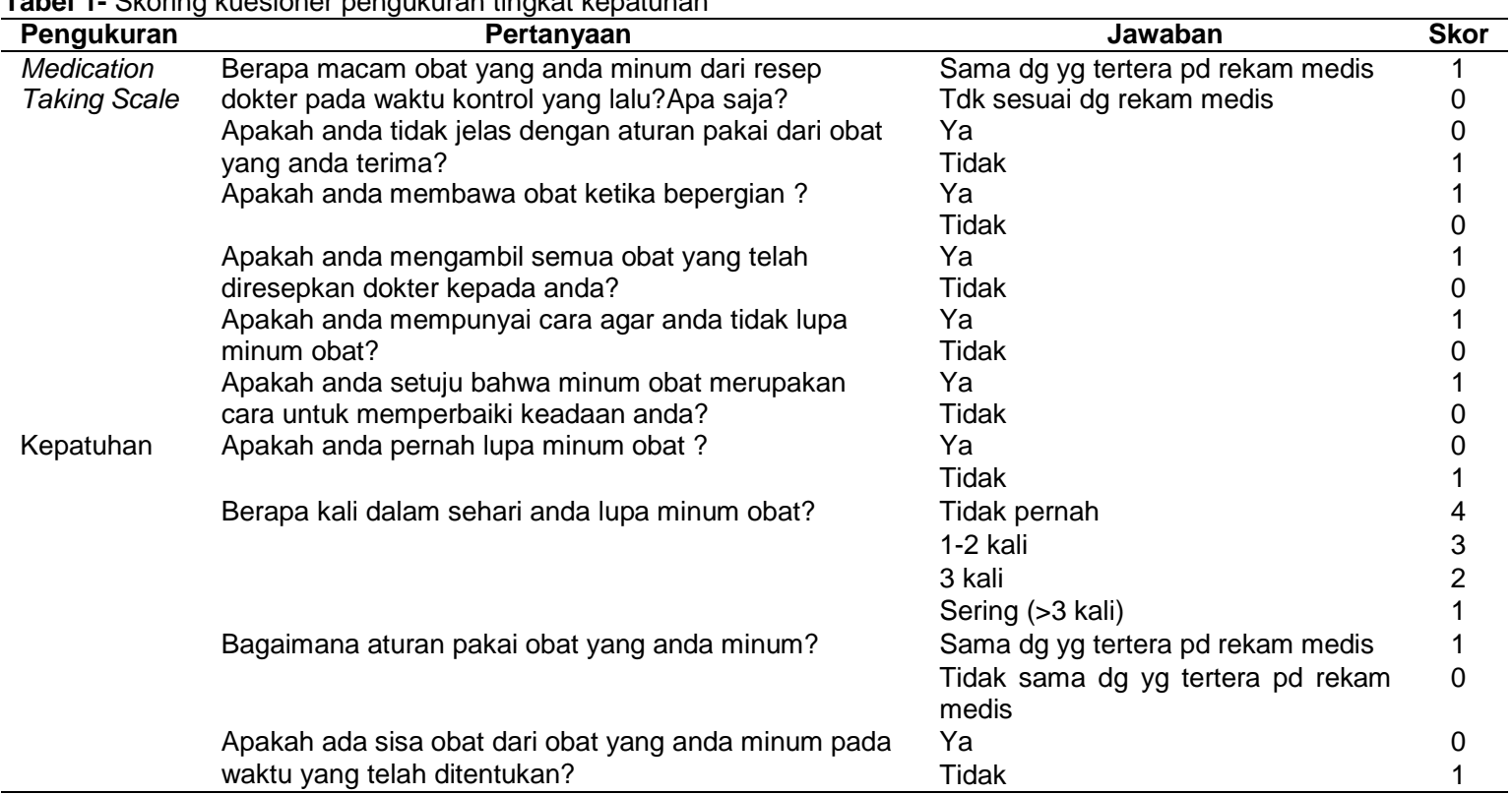


Tabel 2- Klasifikasi Tingkat Kepatuhan Penggunaan Obat

\begin{tabular}{cc}
\hline Skor & Tingkat Kepatuhan \\
\hline $1-4$ & Rendah \\
$5-9$ & Sedang \\
$10-13$ & Tinggi \\
\hline
\end{tabular}

2. Pengukuran Penurunan tekanan darah sistolik = TD bulan lalu- TD bulan ini

3. Analisis hubungan antara kepatuhan dengan penurunan tekanan darah menggunakan korelasi Product moment, di mana $\mathrm{x}$ sebagai skor kepatuhan dan $\mathrm{y}$ sebagai penurunan tekanan darah sistolik, dengan rumus :

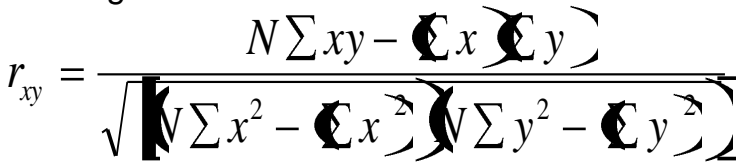

Tabel 3-Interpretasi nilai korelasi

\begin{tabular}{ll}
\hline $\mathbf{R}$ & Interpretasi \\
\hline 0 & Tidak berkorelasi \\
$0,01-0,20$ & Korelasi Sangat Rendah \\
$0,21-0,40$ & Rendah \\
$0,41-0,60$ & Agak Rendah \\
$0,61-0,80$ & Cukup \\
$0,81-0,99$ & Tinggi \\
1 & Sangat Tinggi \\
\hline
\end{tabular}

(Usman dan Akbar, 2000)

\section{HASIL DAN PEMBAHASAN \\ Karakteristik Pasien}

Dari 23 pasien hipertensi rawat jalan di

Rumah Sakit Daerah Surakarta periode September-Oktober tahun 2010, ditemukan pasien perempuan lebih banyak dibanding pasien laki-laki, sedangkan usia didominasi usia $>47$ tahun (tabel 4 )
Tabel 4-Karakteristik Pasien Hipertensi di Rumah Sakit Daerah Surakarta Tahun 2010

\begin{tabular}{cccc}
\hline $\begin{array}{c}\text { Umur } \\
\text { (tahun) }\end{array}$ & \multicolumn{2}{c}{ Jenis Kelamin } & Jumiah \\
\hline $17-31$ & $0(0 \%)$ & $0(0 \%)$ & 0 \\
$32-46$ & $0(0 \%)$ & $3(13,0 \%)$ & 3 \\
$47-60$ & $8(34,8 \%)$ & $12(52,2 \%)$ & 20 \\
Jumlah & $8(34,8 \%)$ & $15(65,2 \%)$ & 23 \\
\hline
\end{tabular}

Hal di atas mungkin terjadi karena wanita mengalami menopause, yang pada kondisi tersebut terjadi perubahan hormonal yaitu terjadi penurunan perbandingan estrogen dan androgren yang menyebabkan peningkatan pelepasan renin, sehinggan dapat memicu peningkatan tekanan darah (Coylewright et al., 2008).

\section{Penyakit Penyerta}

Ditemukan 6 pasien $(26,1 \%)$ tanpa penyakit penyerta dan 17 pasien (73,9\%) menderita hipertensi dengan penyakit penyerta. Penyakit penyerta terbesar yang menyertai hipertensi adalah diabetes mellitus (34,8\%).

\section{Tekanan Darah Pasien}

Dari 23 pasien ditemukan adanya kecenderungan terjadinya penurunan tekanan darah setelah 1 bulan penggunaan obat antihipertensi. Tabel 5 menunjukkan bahwa pada bulan ini (bulan dilakukannya penelitian) ditemukan adanya pasien dengan tekanan darah kategori normal dan prehipertensi, sedangkan bulan sebelumnya tidak ditemukan adanya pasien dengan kategori tersebut.

Tabel 5- Tekanan Darah Pasien di Rumah Sakit Daerah Surakarta Periode September-Oktober Tahun 2010 Menurut Klasifikasi JNC 7

\begin{tabular}{|c|c|c|c|}
\hline Tekanan Darah (mmHg) & Kategori & Bulan lalu & Bulan ini \\
\hline$<120 / 80$ & Normal & $0(0 \%)$ & $5(21,7 \%)$ \\
\hline $130-139 / 80-89$ & Prehipertensi & $0(0 \%)$ & $2(8,7 \%)$ \\
\hline$<140-159 / 90-99$ & Hipertensi stage I & $12(52,2 \%)$ & $10(43,5 \%)$ \\
\hline$\geq 160$ & Hipertensi stage II & $11(47,8 \%)$ & $6(26,1 \%)$ \\
\hline \multicolumn{2}{|c|}{ Jumlah } & $23(100 \%)$ & $23(100 \%)$ \\
\hline
\end{tabular}

\section{Profil Penggunaan Obat}

Pada beberapa pasien hipertensi juga ditemukan adanya gangguan atau penyakit lain sehingga dalam terapinya digunakan juga obat lain untuk mengatasinya (tabel 6) Banyak pasien hipertensi yang membutuhkan dua atau lebih obat antihipertensi untuk mencapai tujuan tekanan darah yang diinginkan. Pemberian terapi obat antihipertensi lebih dari satu, akan meningkatkan kemungkinan tercapainya tekanan darah yang diinginkan (Chobanian, 2003). Pada penelitian ini kombinasi obat antihipertensi yang paling banyak diberikan adalah golongan ACEI dan diuretik (captopril dan HCT) sebesar $34,78 \%$. Pemberian kombinasi tersebut tentunya juga memperhatikan kondisi pasien. 
Tabel 6- Profil Penggunaan Obat Pada Pasien Hipertensi di Rumah Sakit Daerah Surakarta Periode September-Oktober Tahun 2010

\begin{tabular}{|c|c|c|c|c|}
\hline No. & Kelas Terapi & Golongan & Nama Obat & Jumlah \\
\hline \multirow[t]{6}{*}{1} & Antihipertensi & Diuretik & Furosemid & $9(34,8 \%)$ \\
\hline & & & HCT & $10(34,8 \%)$ \\
\hline & & & Spironolakton & $3(13,08 \%)$ \\
\hline & & & Bisoprolol & $7(30,4 \%)$ \\
\hline & & ACEI & Captopril & $20(87,0 \%)$ \\
\hline & & CCB & Diltiazem & $9(39,1 \%)$ \\
\hline \multirow{2}{*}{2} & & & Glikuidon & $3(13,0 \%)$ \\
\hline & & Biguanid & Metformin & $8(34,8 \%)$ \\
\hline 3 & Glikosida Jantung & & Digoxin & $2(8,7 \%)$ \\
\hline \multirow[t]{2}{*}{4} & Antianemia & & Asam Folat & $2(8,7 \%)$ \\
\hline & & & Fero fumarat & $3(13,0 \%)$ \\
\hline \multirow{2}{*}{7} & & & Cimetidine & $1(4,4 \%)$ \\
\hline & & Antasida & Antacid & $3(13,0 \%)$ \\
\hline 8 & Vitamin & Vitamin B & Vitamin B1 & $2(13,0 \%)$ \\
\hline 9 & Antitusif & & Codein & $1(4,4 \%)$ \\
\hline 10 & Mukolitik & & Bromheksin & $1(4,4 \%)$ \\
\hline 11 & Analgesik & Non opioid & Na Diklofenak & $1(4,4 \%)$ \\
\hline 12 & Antibakteri & Kuinolon & Levofloxacin & $1(4,34 \%)$ \\
\hline
\end{tabular}

\begin{tabular}{|c|c|c|c|}
\hline Antihipertensi & & Golongan Obat & Jumlah \\
\hline \multirow{5}{*}{ Tunggal } & & ACEI & $3(13,0 \%)$ \\
\hline & I Jenis & BB & $1(4,4 \%)$ \\
\hline & & ACEI+Diuretik & $8(34,8 \%)$ \\
\hline & 2 jenis & CCB+Diuretik & $1(4,4 \%)$ \\
\hline & & BB+diuretic & $1(4,4 \%)$ \\
\hline \multirow[t]{4}{*}{ Kombinasi } & & $\mathrm{ACEI}+$ diuretic+CCB & $3(13,0 \%)$ \\
\hline & 3 jenis & $\mathrm{ACEI}+$ diuretik+BB & $1(4,4 \%)$ \\
\hline & & $\mathrm{BB}+\mathrm{ACEI}+\mathrm{CCB}$ & $2(8,7 \%)$ \\
\hline & 4 jenis & $\mathrm{ACEI}+$ diuretik+CCB+BB & $3(13,0 \%)$ \\
\hline Jumlah & & & $23(100 \%)$ \\
\hline
\end{tabular}

Evaluasi Kepatuhan Penggunaan Obat Antihipertensi

\section{Keteraturan Pengobatan (Medication Taking Scale)}

Horne (2005) mengatakan bahwa kepercayaan setiap pasien mengenai bentuk penyakitnya memiliki pengaruh yang besar pada keinginan mereka untuk mengikuti saran kesehatan terapi pengobatan. Dari tabel 14, pasien yang teratur dalam penggunaan obat yaitu membawa obat ketika berpergian sebesar 18 pasien $(78,26 \%)$, yang mengambil semua obat yang diresepkan sebesar 21 pasien
$(91,30 \%)$, yang mempunyai cara agar tidak lupa minum obat sebesar 18 pasien $(78,26 \%)$, dan yang setuju minum obat memperbaiki keadaan sebesar 22 pasien (95,65\%). Berdasarkan keterangan yang diberikan pasien, pasien tidak membawa obat ketika berpergian disebabkan karena pasien hanya sebentar meninggalkan rumah, sedangkan sebagian pasien yang tidak mengambil semua obat yang diresepkan disebabkan karena keterbatasan ekonomi pasien, apalagi bila ada tambahan resep yang harus diambil di luar rumah sakit.

Tabel 8- Jawaban Pasien Hipertensi di Rumah Sakit Daerah Surakarta Tahun 2010 terhadap kuesioner Medication Taking Scale

\begin{tabular}{lcc}
\multicolumn{1}{c}{ Pertanyaan } & Ya & Tawaban \\
\hline Pasien jelas dengan aturan pakai obat & $23(100 \%)$ & $0(0 \%)$ \\
Membawa obat ketika berpergian & $18(78,3 \%)$ & $5(21,7 \%)$ \\
Mengambil semua obat yang diresepkan & $21(91,3 \%)$ & $2(8,7 \%)$ \\
Mempunyai cara agar tidak lupa minum obat & $18(78,3 \%)$ & $5(21,7 \%)$ \\
Setuju bahwa minum obat dapat memperbaiki keadaan & $22(95,7 \%)$ & $1(4,3 \%)$ \\
\hline
\end{tabular}

\section{Kepatuhan (adherence)}

Hipertensi merupakan penyakit tanpa gejala, sehingga ketidakpatuhan sangat sering, apalagi pada pasien yang baru diobati. terhitung hanya $50 \%$ pasien yang baru terdiagnosa hipertensi melanjutkan pengobatan sampai 1 tahun. Oleh karena itu, perlu menilai kepatuhan pasien pada awal pengobatan (Saseen dan Maclaughlin, 2007). 
Tabel 9- Jawaban Pasien Hipertensi di Rumah Sakit Daerah Surakarta Tahun 2010 terhadap kuesioner Kepatuhan

\begin{tabular}{lcc}
\hline \multicolumn{1}{c}{ Pertanyaan } & \multicolumn{2}{c}{ Ya Jawaban } \\
\hline $\begin{array}{l}\text { Pernah lupa minum obat } \\
\text { Dapat menjelaskan }\end{array}$ & $14(60,9 \%)$ & $9(39,1 \%)$ \\
$\begin{array}{l}\text { aturan pakai } \\
\begin{array}{l}\text { Ada sisa obat pada } \\
\text { waktu kontrol }\end{array}\end{array}$ & $22(95,7 \%)$ & $1(4,3 \%)$ \\
\hline
\end{tabular}

Dari penelitian ini diketahui bahwa pasien yang lupa minum obat sebesar 14 pasien $(60,87 \%)$ dan pasien yang masih ada sisa obat ketika kontrol sebesar 13 pasien (52,55\%). Menurut keterangan dari pasien, pasien lupa minum obat karena waktu minum obat yang bersamaan dengan waktu kerja atau waktu tidur, sedangkan adanya obat sisa waktu kontrol disebabkan karena waktu kontrol pasien yang berdekatan dengan kontrol berikutnya selain itu juga disebabkan karena pasien lupa minum obat.

\section{Tingkat Kepatuhan Pasien}

Pasien hipertensi di RS Daerah Surakarta mayoritas $(69,6 \%)$ memiliki tingkat kepatuhan penggunaan obat yang tinggi. Tingginya kepatuhan berpengaruh pada peningkatan tercapainya tekanan darah optimum dan penurunan komplikasi hipertensi (WHO,2003). Tingkat kepatuhan penggunaan obat dipengaruhi oleh banyak factor yaitu faktor sosial - ekonomi, faktor sistem kesehatan, faktor kondisi penyakit, faktor terapi dan faktor pasien. Oleh karena itu dalam menyelesaikan masalah tentang kepatuhan pasien tidak sepenuhnya terdapat pada pasien, namun juga dilakukan adanya pembenahan pada sistem kesehatan dan petugas pelayanan kesehatan (WHO, 2003).

Tabel 10-Skor Kepatuhan Pasien Hipertensi di Rumah Sakit Daerah Surakarta Tahun 2010

\begin{tabular}{ccc}
\hline Skor Kepatuhan & Tingkat Kepatuhan & Jumlah (\%) \\
\hline $1-4$ & Rendah & $0(0 \%)$ \\
$5-9$ & Sedang & $7(30,4 \%)$ \\
$10-13$ & Tinggi & $16(69,6 \%)$ \\
\hline
\end{tabular}

\section{Hubungan Antara Kepatuhan dan Penurunan Tekanan Darah}

Kepatuhan pasien sangat diperlukan untuk mencapai keberhasilan terapi utamanya pada terapi penyakit tidak menular. Adanya ketidakpatuhan pasien dapat memberikan efek negative yang sangat besar. Menurut WHO (2003) hampir $75 \%$ pasien dengan diagnosis hipertensi gagal mencapai tekanan darah optimum dikarenakan rendahnya kepatuhan penggunaan obat.

\section{Hubungan Antara Penurunan Tekanan Darah dengan Skor Kepatuhan Pasien di Rumah Sakit Daerah S urakarta Periode September-Oktober Tahun 2010}

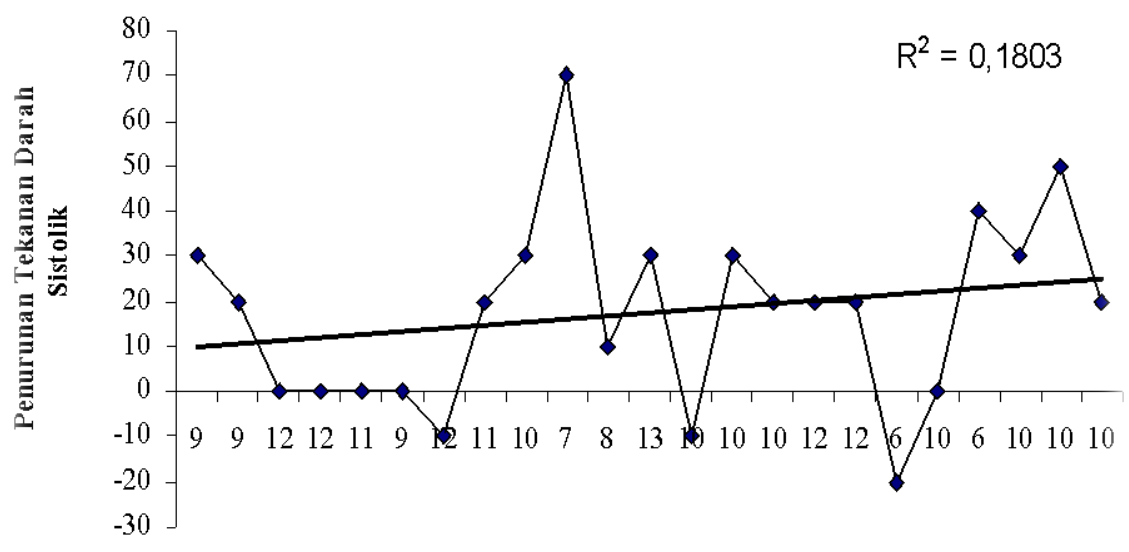

Skor Kepatuhan

Gambar 1-Hubungan Antara Penurunan Tekanan Darah dengan Skor Kepatuhan Pasien di Rumah Sakit Daerah Surakarta Tahun 2010

Pada penelitian ini, sebagian besar pasien mengalami penurunan tekanan darah, dan sebagian kecil tidak mengalami penurunan tekanan darah bahkan tekanan darahnya lebih tinggi dari sebelum pengobatan. Dalam memprediksi resiko penyakit kardiovaskuler, peningkatan tekanan darah sistolik lebih baik dibandingkan peningkatan tekanan darah diastolik. Menurut JNC V, untuk mengevaluasi, mendeteksi, dan memberikan pengobatan hipertensi, tekanan darah sistolik merupakan target untuk mengontrol tekanan darah (Basile, 2002). 
Gambar 1 menunjukkan hubungan penurunan nilai tekanan darah sistolik dan skor kepatuhan. Dari analisis yang dilakukan, dengan menggunakan korelasi product moment, dimana $\mathrm{Y}$ adalah penurunan tekanan darah sistolik dan $\mathrm{X}$ adalah skor kepatuhan, didapatkan nilai $r$ adalah 0,1803 . Nilai $r$ menunjukkan bahwa $18,03 \%$ penurunan tekanan darah dipengaruhi oleh kepatuhan. Dari nilai $r$ tersebut, dapat diinterpretasikan bahwa korelasi antara skor kepatuhan dengan penurunan tekanan darah sangat rendah.

Kegagalan terapi atau tidak tercapainya kesembuhan yang diinginkan terkadang tidak sepenuhnya berasal dari ketidakpatuhan pasien, dalam suatu survey yang telah dilakukan, banyak dokter yang tidak meresepkan cukup obat untuk mengontrol tekanan darah tinggi pasiennya (Basile, 2002).

\section{KESIMPULAN}

Pasien hipertensi di RS Daerah Surakarta memiliki tingkat kepatuhan sedang $(30,4 \%)$ dan tinggi ( 69,6\%). Ditemukan bahwa korelasi antara kepatuhan dengan penurunan tekanan darah sangat rendah, dimana tingkat kepatuhan mempengaruhi keberhasilan terapi sebesar $18,03 \%$.

\section{DAFTAR PUSTAKA}

Armilawaty, Amalia, H., Amiruddin, R., 2007, Hipertensi Dan Faktor Resikonya Dalam Kajian Epidemiologi, Bagian Epidimiologi FKM UNHAS, (online), http : // ridwanamiruddin.wordpress.com diakses pada 23 Februari 2010

Basile, J.N., 2002, Systolic Blood Pressure, (online), http://www.bmi.com/content/325/7370/917.extract diakses pada 19 Januari 2011.

BPOM, 2006, Kepatuhan Pasien: Faktor Penting dalam Keberhasilan Terapi, Info POM, Vol 7 No 5

Chobanian, A.V., Bakris, G.L., Black, H.R., Cushman, W.C., Green, L.A., and Joseph, L.L., 2003, The Seven Report of The Joint National Comitte on Prevention, Detection, Evaluation, and Treatment of High Blood Pressure: The JNC 7 Express, U.S. Department of Health and Human Services, New York.

Coylewright, M., Reckelhoff, J.F., Ouyang, P., 2008, Hypertension,(online), http://hyper.ahajournals.org/eri/content/full/51/4/952 diakses pada 17 Januari 2011

Horne, R., 2005, Pharmacy Practice, School of Pharmacy, Univercity London, London UK

Saseen, J.J., dan Maclaughlin E.J., 2007, Hypertension, hal 139-168, dalam Dipiro, et al, Pharmacotherapy A Patophysiological Approach, $7^{\text {th }}$ ed, McGraw Hill, Newyork.

Usman, H. dan Akbar, R.P.S., 2000. Pengantar Statistika, Bumi Aksara, Jakarta

Wibawa, R.A, 2008, Hubungan Antara Cara Bayar Dengan Kepatuhan Berobat Pada Pasien Hipertensi Rawat Jalan, (online), http://digilib.uns.ac.id.diakses tanggal 27 Februari 2010.

WHO, 2003, Adherence To Long-Term Therapies, WHO Library Cataloguing, Switzerland. 